\title{
When is bigger better? Early marine residence of middle and upper Columbia River spring Chinook salmon
}

\author{
Londi M. Tomaro ${ }^{1 *}$, David J. Teel ${ }^{2}$, William T. Peterson ${ }^{3}$, Jessica A. Miller ${ }^{1}$ \\ ${ }^{1}$ Coastal Oregon Marine Experiment Station, Hatfield Marine Science Center, Department of Fisheries and Wildlife, \\ Oregon State University, 2030 SE Marine Science Drive, Newport, Oregon 97365, USA \\ ${ }^{2}$ NOAA Fisheries, Northwest Fisheries Science Center, Manchester, Washington 98353, USA \\ ${ }^{3}$ NOAA Fisheries, Northwest Fisheries Science Center, Newport, Oregon 97365, USA
}

\begin{abstract}
Early ocean residence is considered a critical period for juvenile salmon although specific survival mechanisms are often unidentified and may vary by species or life stage. Columbia River spring-run Chinook salmon Oncorhynchus tshawytscha abundance has declined dramatically since the early 1900s. To elucidate mechanisms of early marine survival, we tested the 'bigger-is-better' and 'stage-duration' aspects of the 'growth-mortality' hypothesis, which posits that size and growth rate are important for future abundance. We tested the 'match-mismatch' hypothesis to determine whether early marine growth was related to indices related to regional productivity, including spring transition timing and copepod community composition. We generated estimates of individual size at ocean entry and capture, marine growth rate, early marine migration rate, and emigration timing using data from ocean surveys, genetic stock-assignment, and otolith analyses of juveniles collected across 8 yr between 1998 and 2008. Size at capture and marine growth rate after $\sim 30 \mathrm{~d}$ marine residence were positively related to future adult returns, whereas size at marine entry was not. Growth rate was not significantly related to indices of secondary production, but size at capture was significantly greater when lipid-rich copepods dominated. Although future adult abundance was not related to emigration timing, juveniles migrated more slowly when copepod biomass was high, perhaps responding to foraging conditions. Overall, processes during early ocean residence appear to be more important for cohort size establishment than those at marine entry. Approaches that combine genetic and otolith analyses have great potential to provide information on stock-specific variation in survival mechanisms.
\end{abstract}

KEY WORDS: Survival mechanisms · Juvenile salmon · Columbia River · Ocean residence • Otolith back-calculation

\section{INTRODUCTION}

Pacific salmon Oncorhynchus spp. are broadly distributed anadromous fishes. Early ocean residence is assumed to be a critical period for salmon based on several lines of evidence. For example, future adult abundance has been positively correlated with juvenile abundance after initial ocean residence (Pearcy 1992) and survival rates of several stocks were correlated regionally, i.e. at scales within $\sim 500 \mathrm{~km}$ (Peter- man et al. 1998, Hare et al. 1999, Pyper et al. 2005), which imply the establishment of cohort size soon after ocean entry. Survival has also been related to physical factors, such as river velocity, upwelling intensity, and water temperature (Scheuerell \& Williams 2005, Petrosky \& Schaller 2010), and biological factors, such as body size, primary production, and food chain structure (Henderson \& Cass 1991, Beamish \& Mahnken 2001, Peterson \& Schwing 2003, Beamish et al. 2004, Peterson 2009), in both the fresh- 
water and marine environment (for review, see Pearcy \& McKinnell 2007). However, specific mechanisms of mortality are rarely identified and likely vary with species or life history. Overall, the relative importance of growth- versus predation-mediated processes (i.e. bottom-up versus top-down) during the early life history is not well understood.

Chinook salmon Oncorhynchus tshawytscha are distributed along the Pacific Rim and, in North America, spawn from central California to western Alaska (Beacham et al. 2006). Juveniles spend weeks, months, or over a year in freshwater before emigrating to the ocean (Taylor 1990), where most reside for 2 or more years (Quinn \& Myers 2004). Marine distributions and migration patterns appear to vary by geographic origin and adult run time, i.e. spring, summer, or fall (Weitkamp 2010). The Columbia River is a major producer of Chinook salmon and supports numerous populations with diverse life-history and ecological characteristics (Waples et al. 2008). However, most populations have decreased substantially since the development of the hydropower system beginning in 1933. In particular, runs of spring Chinook salmon have declined throughout most of the basin, and certain populations, such as the upper Columbia River spring run, are listed as endangered (Good et al. 2005). A better understanding of the relative importance of freshwater versus marine mortality during the early life history of Columbia River spring Chinook salmon would aid conservation and management efforts.

Columbia River spring Chinook salmon generally emigrate after a year in freshwater (Rich 1920, Fryer 2009), migrate northward quickly (Trudel et al. 2009), and return to spawn as adults after 2 or more years at sea (Myers et al. 1998). Although the abundance of adults returning to the Columbia River is positively correlated with the abundance of precocial spawners the previous year (counts) and yearlings in coastal waters 2 yr earlier (fish $\mathrm{km}^{-1}$ ), these relationships account for $<35 \%$ of the variation in adult abundance $\left(\mathrm{r}^{2}=26, \mathrm{p}=0.11\right.$ and $\mathrm{r}^{2}=0.34, \mathrm{p}=0.06$, respectively) over the last decade (National Oceanic and Atmospheric Administration [NOAA] unpubl. data, Columbia River Data Access in Real Time: www.cbr.washington.edu/dart/dart.html). Additionally, these relationships do not provide insight into mechanisms of survival. However, there is evidence that juvenile body size (Zabel \& Williams 2002, Duffy \& Beauchamp 2011) and timing of marine entry (Scheuerell et al. 2009) influence subsequent survival. The potential influences of body size and timing on subsequent survival are well-described in the 'growth-mortality' and 'match-mismatch' hypotheses.

The growth-mortality hypothesis combines aspects of the 'bigger-is-better' and the 'stage-duration' hypotheses. The bigger-is-better hypothesis states that larger fish have higher survival because they more successfully avoid predators (Butler \& Pickett 1988, Miller et al. 1988) and capture prey (Bailey \& Batty 1983, Blaxter 1986). The stage-duration hypothesis posits that faster growing fish remain susceptible to predation for a shorter period (Houde 1987, 2008, Takasuka et al. 2004). Growth rate determines the span of a life stage (Chambers \& Leggett 1987) and is often used as a proxy for stage duration (Takasuka et al. 2004). Therefore, larger size or faster growth rate may confer a survival advantage to juvenile salmon. However, it is not clear when size is important. Zabel \& Achord (2004) found evidence for length-related mortality within populations of Chinook salmon but only examined juveniles, 50 to $100 \mathrm{~mm}$ in length, during their freshwater residence. Size variation within a population can result from growth variation or selective mortality at various points in the life history. For juvenile salmonids, it is not clear if size at marine entry, which may influence susceptibility to a new suite of predators (Pearcy 1992, Emmett et al. 2006, Emmett \& Krutzikowsky 2008), is as important as size later in the life history such as after the first ocean summer, which may influence survival during the subsequent winter (Beamish \& Mahnken 2001, Moss et al. 2005, Cross et al. 2009).

The match-mismatch hypothesis, originally established for first-feeding larvae (Cushing 1974) and later expanded to other early life stages (Anderson 1988), states that young fish have higher survival if they experience spatiotemporal overlap with their food source (Cushing 1990). It is expected that year classes entering the ocean during periods with better foraging conditions will have higher survival. For example, pink salmon Oncorhynchus gorbuscha released into Prince William Sound during peak zooplankton abundance survived better than juveniles released during less favorable foraging conditions (Cross et al. 2008). Although juvenile Chinook salmon primarily consume juvenile fish, euphausiids, and decapod larvae (Daly et al. 2009), researchers hypothesized that their marine growth and survival would be enhanced during years in which the nutritional quality of lower trophic levels was enhanced due to the presence of a lipid-rich copepod community (Hooff \& Peterson 2006, Litzow et al. 2006, Keister et al. 2011). The composition and abundance of the copepod community in the California Current 
is influenced by upwelling frequency and intensity, and basin scale climate factors (Hooff \& Peterson 2006). Furthermore, the timing of seasonal productivity along the west coast of the US is regulated by the spring transition, which is the switch from predominantly downwelling conditions in winter to predominantly upwelling conditions in summer (for review, see Checkley \& Barth 2009). There is a lag of $\sim 7$ to $10 \mathrm{~d}$ between the onset of upwelling and increases in primary production (Henson \& Thomas 2007), and copepod biomass increases during the upwelling season (Hooff \& Peterson 2006). Juvenile salmon may encounter more productive waters if they enter the ocean later in the upwelling season. Therefore, if temporal and spatial overlap with certain trophic conditions during early marine residence is important, early marine growth should be related to indices of the timing, abundance, and composition of regional secondary production.

In salmonids, evaluations of the bigger-is-better hypothesis often rely on data from individuals released from hatcheries (e.g. Bilton et al. 1982, Unwin 1997) or sampled during passage over a particular dam (e.g. Zabel \& Achord 2004). These approaches are biased towards hatchery fish or preclude a clear separation of size at marine entry from size at other points in the life history. Few studies on salmonids have effectively evaluated when bigger is actually better. Furthermore, more precise estimates of the date of marine entry would help evaluate the importance of emigration timing. Therefore, we combined data from ocean surveys, genetic stock identification, and otolith structural and chemical analysis to estimate individual size, timing of marine entry, and early marine growth and migration rates for Columbia River spring Chinook across 8 yr. Our samples included a mixture of all ocean-caught individuals, both hatchery and naturally produced, as this is representative of the population as a whole. We examined variation in juvenile size at 2 periods in the life history-marine entry and after $\sim 30 \mathrm{~d}$ of marine residence - and growth during this early marine period to evaluate the growth-mortality hypothesis. We also compared juvenile size at capture, emigration timing, and growth rate and migration rate after marine entry with indicators of the timing and relative magnitude of marine productivity to evaluate the match-mismatch hypothesis.

\section{MATERIALS AND METHODS}

\section{Fish collection and processing}

Juvenile salmon were collected during NOAA cruises off the coasts of Washington and Oregon during the last 2 wk of May and June from 1998 to 2008. The years 2001 and 2005 were removed from the analysis because there were inadequate numbers of fish and, therefore, otoliths collected $(<20)$. Fish were collected using a $30 \mathrm{~m}$ wide by $20 \mathrm{~m}$ deep surface rope trawl (NET Systems Nordic 264) towed for 30 min at $\sim 6 \mathrm{~km} \mathrm{~h}^{-1}$ and frozen within $30 \mathrm{~min}$ of capture (Fig. 1; study area described in Daly et al. 2009). Salmon were later thawed, and each juvenile
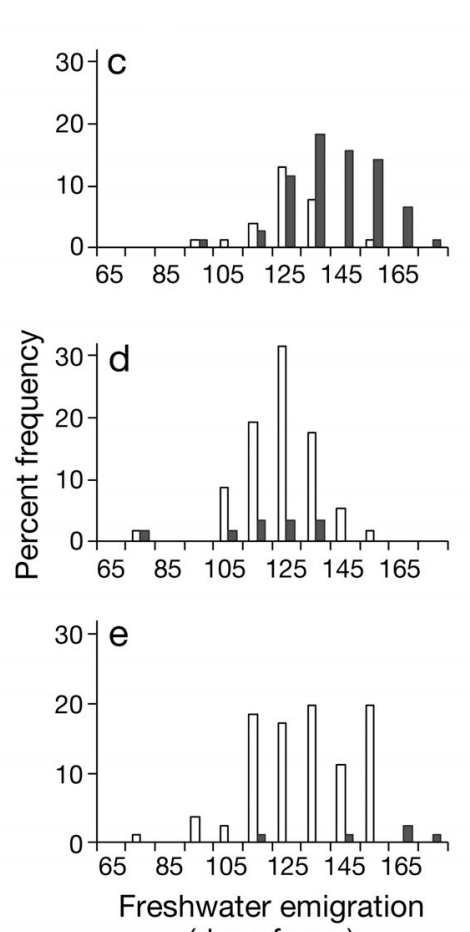

(day of year)

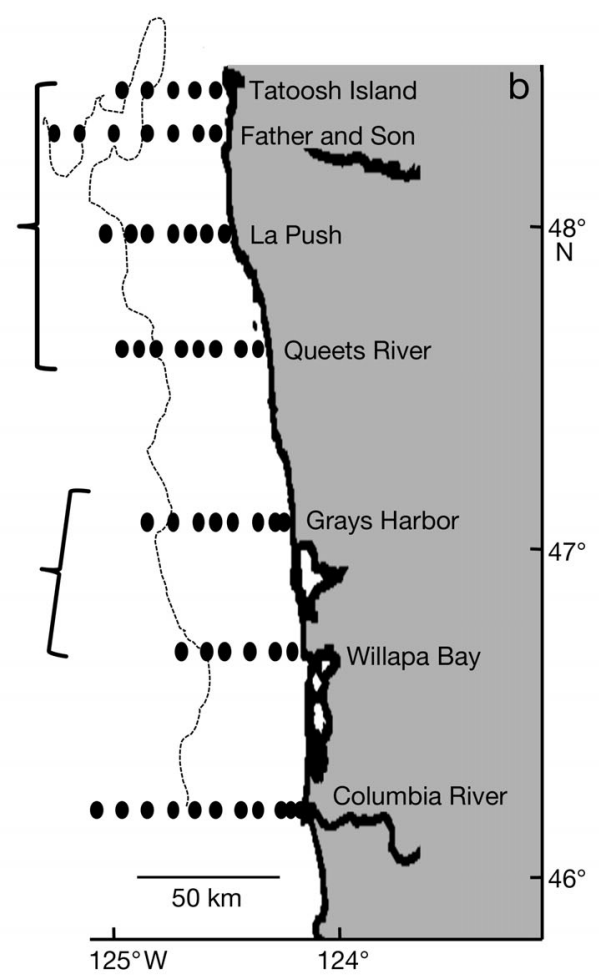

Fig. 1. (a) Sampling area relative to the west coast of North America. (b) Approximate position of transects and sample locations relative to the coast and shelf break (dotted line). Frequency distributions of freshwater emigration dates are included for fish collected at (c) Tatoosh Island, Father and Son, La Push, and Queets River ( $\mathrm{n}=77$ ); (d) Grays Harbor and Willapa Bay $(\mathrm{n}=57)$; and (e) Columbia River $(n=81)$ transects for all years combined. May (white bars) and June (gray bars) collections. Sample sizes include fish for which residence times could be estimated 
was measured, weighed and checked for a codedwire tag (CWT) and a passive integrated transponder (PIT) tag. Samples of fin tissues for genetic analysis and otoliths were removed.

All individuals included in this study were genotyped at 13 standardized microsatellite DNA loci following the procedures outlined in Teel at al. (2009) and assigned to the mid-upper Columbia River spring Chinook salmon stock group using baseline data from the genetic database described by Seeb et al. (2007). This stock group accounted for $23 \%$ of the spring-run Chinook salmon collected on the NOAA cruises between 1999 and 2008. Stock assignments were made with the genetic stock identification program ONCOR (Kalinowski et al. 2007) and the likelihood model of Rannala \& Mountain (1997). The mid-upper Columbia River genetic stock group includes the Mid Columbia River spring-run and Upper Columbia River springrun evolutionarily significant units (ESUs), which spawn in Columbia River tributaries east of the Cascade Mountains, excluding the Snake River (Myers et al. 1998). Seeb et al. (2007) found in evaluations of genetic baseline assignment accuracies that $\sim 5.9 \%$ of individuals from other Columbia River spring-run stock groups (Snake River, Willamette River, and lower Columbia River) were incorrectly identified as belonging to the mid-upper Columbia River spring stock (D. J. Teel, NOAA, Manchester, WA, unpubl. data). In this study, 79\%

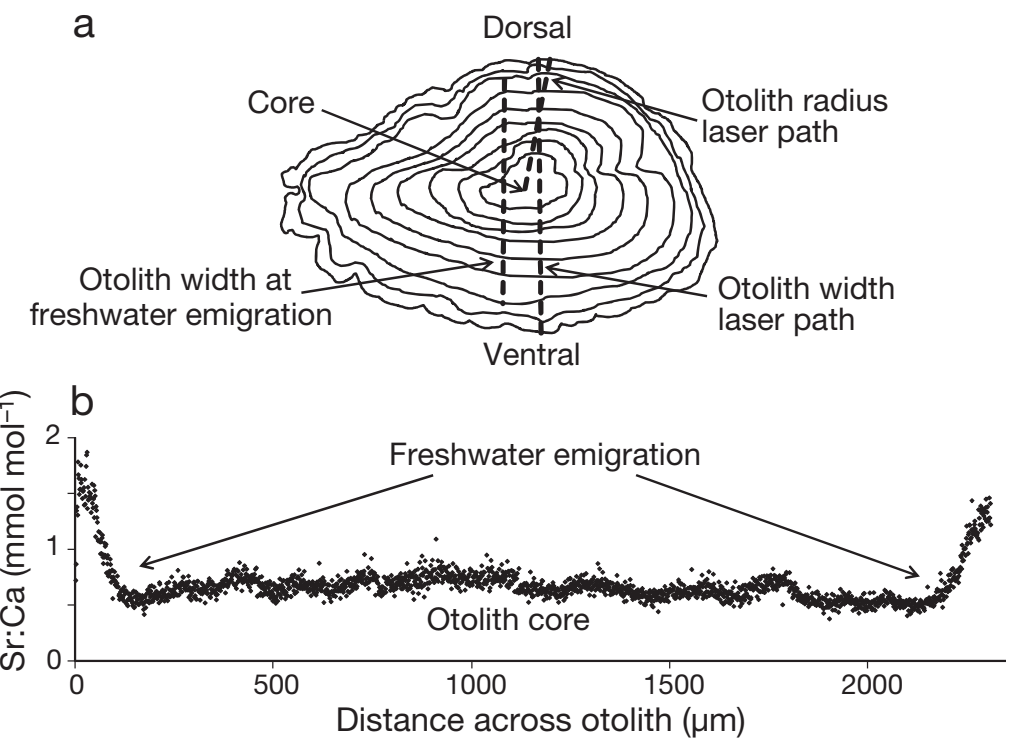

Fig. 2. Oncorhynchus tshawytscha. Schematic of a sagittal otolith and representative Sr:Ca ratio profile. (a) Core, otolith width at freshwater emigration, and laser path for otolith radius and width measurements are identified. (b) $\mathrm{Sr}: \mathrm{Ca}$ ratio across otolith of the individuals used had assignment probabilities $>80 \%$.

We used 6 stock-specific juvenile metrics to test the growth-mortality and match-mismatch hypotheses, including fork length $(\mathrm{FL} ; \mathrm{mm})$ at freshwater emigration and ocean capture; growth rate during initial marine residence; date of freshwater emigration relative to physical and biological indicators of the spring transition to predominantly upwelling conditions; and migration rate between the points of freshwater emigration and ocean capture. Otolith structural and chemical analyses were used to generate all of these metrics except for size at capture, which was determined from measurements of body size of all mid-upper Columbia River spring Chinook juveniles collected in the study. Otoliths were available for a subset of those juveniles.

\section{Otolith preparation, analyses, and interpretation}

Otolith Sr:Ca ratio is often used to reconstruct diadromous migrations when freshwater $\mathrm{Sr}: \mathrm{Ca}$ ratio is distinct from marine waters (Secor 1992, Miller et al. 2010a). The Sr:Ca ratio in the Columbia River is lower than and, thus, distinguishable from oceanic waters (Miller et al. 2011). Therefore, we used otolith chemical and structural analyses to determine when juveniles left freshwater and entered brackish or oceanic habitats, i.e. 'freshwater emigration' (Miller et al. 2010a, 2011). Because variation in water $\mathrm{Sr}$ :Ca ratio is limited above salinities of 8 to 10 (Kraus \& Secor 2004a, Zimmerman 2005, Miller et al. 2010a), we used otolith Sr:Ca ratio to identify transitions from fresh to brackish or oceanic waters but not to separate estuarine and ocean residence. Hereafter, we use 'marine' when referring to brackish and oceanic residence.

Sagittal otoliths were measured along the dorsal-ventral axis at the widest point using image analysis, and the left otolith was ground using wet-or-dry paper and lapping film to expose the dorsal-ventral growth axis (Fig. 2a). Otoliths were otherwise prepared with standard procedures for elemental analysis as described in Miller (2009). Otolith $\mathrm{Sr}$ and Ca were measured using laser ablation-inductively coupled plasma mass spectrometry (LA-ICPMS). Data were collected along a transect that 
included either the (1) otolith radius (OR) from core to dorsal edge ( $52 \%$ of otoliths) or (2) otolith width (OW) (48\% of otoliths) (Fig. 2a). It was easier to interpret chemical data from scans of the entire growth axis; therefore, when analyzing otoliths from the second group of fish, data were collected along the otolith width rather than the radius. The laser was set at a pulse rate of $8 \mathrm{~Hz}$ and translated across the sample at $5 \mu \mathrm{m} \mathrm{s}^{-1}$ with a spot size of 30 or $50 \mu \mathrm{m}$. Normalized ion ratios were converted to elemental ratios using a glass standard from the National Institute of Standards and Technology (NIST 612) (Miller 2007) and converted to molar ratios. Instrument precision (mean percent relative standard deviation) based on NIST 612 was $3.2 \%$ for $\mathrm{Ca}$ and $3.7 \%$ for Sr across all samples and days $(\mathrm{n}=53)$. We used a carbonate standard developed by the United States Geological Survey (MACS-1) to assess accuracy ( $\mathrm{Sr}$ :Ca ratio = $2 \%, \mathrm{n}=18$ ).

Structural analysis was combined with Sr:Ca ratio data to determine otolith size at freshwater emigration and estimate the date of freshwater emigration. After ablation, we captured digital images using a Leica DC300 camera coupled with a Leica MZ95 stereoscope $(20 x)$ or a Leica DM1000 compound microscope $(40 \times, 100 \times, 200 x$, and 400x) and performed image analysis with ImagePro® Plus (Media Cybernetics). For each individual, the OR or OW at the time of freshwater emigration was determined by the initial and abrupt increase in otolith Sr:Ca ratio, which indicates exit from freshwaters, prior to stabilizing at marine values (Fig. 2b) (Miller et al. 2010a, 2011). In order to use a consistent metric (OW) for back-calculation of body size, we estimated OW for fish with OR scans. Juvenile Chinook salmon deposit otolith increments daily (Neilson \& Geen 1982, 1985). Therefore, the paired opaque and translucent increments deposited after the initial and abrupt increase in $\mathrm{Sr}: \mathrm{Ca}$ ratio were counted to determine duration of marine residence. Increment counts were completed twice at least $2 \mathrm{~d}$ apart and the error between counts was calculated.

\section{Back-calculation of size and growth}

We used 8 PIT-tagged juvenile Chinook salmon with known size and migration histories collected in the Columbia River estuary during 2008 to evaluate the assumption that otolith and somatic size are coupled (Campana \& Jones 1992).

We compared direct and proportional back-calculation approaches for estimating size at tagging. For direct back-calculation, we used a relationship based on yearling spring Chinook salmon from the interior Columbia River basin that were collected in coastal waters from 1999 to $2008\left(r^{2}=0.82, n=362, p<0.001\right)$ (Eq. 1):

$$
\begin{aligned}
\ln \left(\mathrm{FL}_{\mathrm{T}}\right)= & 1.126( \pm 0.028 \mathrm{SE}) \times \ln \left(\mathrm{OW}_{\mathrm{T}}\right) \\
& -3.69( \pm 0.21 \mathrm{SE})
\end{aligned}
$$

where $\mathrm{FL}_{\mathrm{T}}=$ fork length $(\mathrm{mm})$ at tagging, and $\mathrm{OW}_{\mathrm{T}}=$ otolith width $(\mu \mathrm{m})$ at tagging. Overall, there was a small decline in otolith size for larger juvenile sizes, which resulted in underestimation of size for fish $>165 \mathrm{~mm}$ FL by $\sim 8 \%$. Given that the majority of fish emigrate from the Columbia River at sizes $<175 \mathrm{~mm}$ FL (Rich 1920, Giorgi et al. 1994, Tiffan et al. 2000), we felt that using Eq. (1) was warranted. For proportional back-calculation, we used Eq. (2) (Francis 1990):

$$
\begin{aligned}
\ln \left(\mathrm{FL}_{\mathrm{T}}\right) & =\left\{\left[1.126 \times \ln \left(\mathrm{OW}_{\mathrm{T}}\right)-3.69\right] /[1.126\right. \\
& \left.\left.\times \ln \left(\mathrm{OW}_{\mathrm{C}}\right)-3.69\right]\right\} \times \ln \left(\mathrm{FL}_{\mathrm{C}}\right)
\end{aligned}
$$

where $\mathrm{OW}_{\mathrm{C}}=$ otolith width at capture, and $\mathrm{FL}_{\mathrm{C}}=$ fork length at capture.

We compared 2 approaches for estimating individual growth rate. (1) We examined the correlation between observed mean somatic growth rate and mean increment width from the time of tagging to capture for the 8 individuals. Increment width was measured twice and measurements had $\geq 94 \%$ agreement. (2) We estimated mean growth rate by determining the difference between size at capture and back-calculated size at tagging and dividing by the days between tagging and capture as determined using tagging and capture dates. For ocean-caught individuals, growth is presented as percent body length per day $\left(\% \mathrm{bl} \mathrm{d} \mathrm{d}^{-1}\right)$ based on estimated size at freshwater emigration. To evaluate back-calculation methods, we used Pearson's correlation coefficient to compare (1) observed size at tagging with direct and proportional estimates of size at tagging and (2) observed growth rate with mean increment width and estimated growth rate.

\section{Migratory characteristics}

To determine individual date of freshwater emigration, the duration of marine residence was subtracted from the date of capture. We also estimated marine migration rate for each individual. Marine migration distance was conservatively estimated as the linear distance between the mouth of the Columbia River $\left(46.253^{\circ} \mathrm{N}, 124.059^{\circ} \mathrm{W}\right)$ and the cap- 
ture station plus $32.1 \mathrm{~km}$ to account for travel through the estuary (Chawla et al. 2008). We divided the migration distance $(\mathrm{km})$ by the marine residence time (d) to calculate the mean migration rate $\left(\mathrm{km} \mathrm{d}^{-1}\right)$ for each fish, which was converted to body lengths per second ( $\mathrm{bl} \mathrm{s}^{-1}$ ) based on estimated size at freshwater emigration.

\section{Indicators of survival}

The smolt-to-adult ratio (SAR) is an indicator of overall survival of a population or stock group (Ward \& Slaney 1988, Beckman et al. 1999). Determination of SARs requires extensive data on juvenile production and natural and fishing mortality rates. SARs estimates have been developed for 2 hatchery and 2 wild stocks of mid-upper Columbia River spring Chinook (Tuomikoski et al. 2011) but are not available for the other hatcheries and wild runs in the genetic stock group. Adult returns to Priest Rapids Dam (-2 yr lag), the first Columbia River mainstem dam upstream of the Snake River, were strongly correlated with the SARs for Cle Elum ( $\mathrm{r}=0.91, \mathrm{n}=7$ ) and Leavenworth $(r=0.93, n=7)$ hatcheries, and for Entiat and Methow ( $\mathrm{r}=1.0, \mathrm{n}=3$ ) and Wenatchee wild runs $(\mathrm{r}=1.0, \mathrm{n}=2)$. Therefore, because we were interested in all components of the genetic stock, we used spring run adult returns to Priest Rapids Dam (www.cbr.washington.edu/dart/) as an indicator of survival. Adult returns were lagged 2 yr because the majority of mid and upper Columbia River spring Chinook salmon return after 2 yr in the ocean (Myers et al. 1998). For example, in 2008 nearly all (98.9\%) of the returning adults had emigrated after $1 \mathrm{yr}$ in freshwater and most (77.5\%) returned 2 yr after emigration (Fryer 2009).

\section{Growth-mortality hypothesis}

If interannual variation in size at the end of freshwater residence is consistently important to cohort success, then we expect size at freshwater emigration to be positively related to adult returns. However, if early marine growth or size-selective predation are consistently important to cohort success, size at capture after $\sim 30 \mathrm{~d}$ marine residence would be more strongly related to adult returns than size at freshwater emigration. Furthermore, if early marine growth rate is important for future survival, then we expect marine growth rates to be positively correlated with adult returns. Therefore, we examined the correlations between adult returns and juvenile size and growth. For those metrics that were correlated with future abundance, we quantified the relationships using simple linear regression. To further quantitatively evaluate the influence of the size and growth rate, we performed multiple linear regression to develop a hindcast model. Adult returns to Priest Rapids Dam were natural log-transformed, and all metrics had normal error distributions and were homoscedastic. We ranked the models according to their Akaike Information Criterion adjusted for small sample size (AICc) and the model with the lowest AICc was considered the most parsimonious.

\section{Indices of production}

To evaluate the match-mismatch hypothesis, we used 4 indicators of annual variation in productivity and temporal overlap between juvenile salmon and secondary production. For productivity we used 2 indicators of the copepod community that are based on data collected biweekly $\sim 9 \mathrm{~km}$ offshore of Newport, Oregon $\left(44.65^{\circ} \mathrm{N}, 124.18^{\circ} \mathrm{W}\right)$. We used (1) the anomaly of the total biomass of boreal copepods, which is the monthly logged biomass estimate (mg $\mathrm{C} \mathrm{m}^{-3}$ ) minus the 15-yr monthly mean averaged over May to September (W. T. Peterson, NOAA, Newport, OR, unpubl. data) and (2) an index of the copepod community structure (Keister et al. 2011). The Copepod Community Index (CCI) consists of the rotated Axis 1 scores of a non-metric multidimensional scaling ordination of species abundance by sample date from 1996 to 2010 (Keister et al. 2011). During spring and summer, positive anomalies of copepod biomass and negative CCI indicate the presence of a 'northern community', i.e. cold-water neritic (shelf-resident) taxa that are large and lipid-rich, as well as stronger equatorward transport and upwelling conditions (Hooff \& Peterson 2006). Coastal copepod biomass is higher when cold, dense water is nearshore (Keister et al. 2009), and the CCI is lower when upwelling is more intense and regional and basinscale water temperature anomalies are cooler (Keister et al. 2011). Although juvenile Chinook salmon do not directly consume copepods (Peterson et al. 1982, Brodeur \& Pearcy 1990, Schabetsberger et al. 2003, Daly et al. 2009), these copepod metrics may be indicative of the nutritional quality of the food web supporting juvenile salmon and their prey.

To examine the influence of temporal overlap, we used indicators based on the physical and biological changes associated with the transition to upwelling conditions. The physical spring transition $\left(T_{P}\right)$ is 
defined as the 1st day that the 10-d average for upwelling indices was positive and sea level height was negative (Logerwell et al. 2003). The biological spring transition $\left(\mathrm{T}_{\mathrm{B}}\right)$ is defined as the 1st day that zooplankton samples from $9 \mathrm{~km}$ offshore of Newport, Oregon contain an upwelling-associated copepod community that dominates in the summer (Peterson \& Schwing 2003, Hooff \& Peterson 2006). Therefore, we examined how interannual variation in emigration timing was related to these physical and biological transitions. We determined the number of days between juvenile emigration and the physical and biological spring transition dates, hereafter referred to as the physical transition lag $\left(\mathrm{FE}-\mathrm{T}_{\mathrm{P}}\right)$ and the biological transition lag $\left(\mathrm{FE}-\mathrm{T}_{\mathrm{B}}\right)$.

\section{Match-mismatch hypothesis}

We predicted that early marine growth rate would be positively related to (1) $\mathrm{FE}-\mathrm{T}_{\mathrm{P}}$ and $\mathrm{FE}-\mathrm{T}_{\mathrm{B}}$ because growth conditions are expected to improve as the upwelling season progresses; (2) the copepod biomass anomaly because higher copepod biomass is generally associated with the dominance of large, cold-water species with high lipid content; and (3) negative values of the CCI because they are also associated with the dominance of lipid-rich, coldwater copepod species. This approach allowed us to determine if juvenile growth is related to the timing of emigration relative to the onset of seasonal production, which we used because indices of Chinook salmon prey are not available, as well as formally evaluate the hypothesis that juvenile salmonid growth is enhanced during years in which the northern community dominates (Keister et al. 2011).

\section{RESULTS}

\section{Fish collection}

All juveniles were captured between 21 May and 29 June and most (80\%) emigrated from freshwater between 18 April and 30 May (Fig. 1). Size at capture ranged from 102 to $261 \mathrm{~mm}$ with an overall mean $\pm \mathrm{SE}$ of $161 \pm 1 \mathrm{~mm}$. Nearly three-quarters of the fish (74\%) were collected along 3 transects: LaPush, Grays Harbor, and the Columbia River (Appendix 1). In general, the fish collected in June were farther north of the Columbia River than those collected in May (Appendix 1). The CWT prevalence was 36\% for all mid-upper Columbia River spring Chinook salmon collected and $28 \%$ for the subset used for otolith analyses. The actual proportion of hatchery origin fish is likely higher than the CWT prevalence because just 50 to $78 \%$ of the hatchery-reared fish in this stock were CWT and 53 to $80 \%$ were marked (adipose fin-clipped) during the years of this study. We had no way to definitively group untagged and unmarked fish as 'wild' or 'hatchery'.

\section{Migratory characteristics}

Some fish $(\mathrm{n}=20)$ had no discernable elevation of Sr within their otolith. Laboratory studies indicate an increase in otolith Sr occurs within 2 to $4 \mathrm{~d}$ of exposure to salinity (Miller 2011). Therefore, we used a $1 \mathrm{~d}$ marine residence time for those fish, which were included in analyses of freshwater emigration but not migration rate.

Size at freshwater emigration, size at capture, date of freshwater emigration, marine migration rate, and FE- $T_{P}$ and $F E-T_{B}$ varied among years (Table 1)

Table 1. Oncorhynchus tshawytscha. Juvenile metrics (mean \pm SE) and adult returns to Priest Rapids Dam for each juvenile emigration year. Number of days between freshwater emigration (FE) and the physical $\left(\mathrm{T}_{\mathrm{P}}\right)$ and biological $\left(\mathrm{T}_{\mathrm{B}}\right)$ spring transitions $=F E-T_{P}$ and FE- $T_{B}$, respectively. Range of sample sizes (n) are presented for each otolith-derived metric (sample size used to calculate fish size at capture in parentheses). Sample sizes for otolith-derived metrics were low in 2004 because 13 fish showed no sign of freshwater emigration. FL: fork length, bl: body length

\begin{tabular}{|c|c|c|c|c|c|c|c|c|c|c|}
\hline $\begin{array}{l}\text { Emi- } \\
\text { gration } \\
\text { (yr) }\end{array}$ & $\begin{array}{l}\text { Size (FL, } \\
\text { FE }\end{array}$ & $\begin{array}{l}\mathrm{mm} \text { ) at } \\
\text { capture }\end{array}$ & $\begin{array}{l}\text { residence } \\
\text { (d) }\end{array}$ & $\begin{array}{c}\text { Marine } \\
\text { growth rate } \\
\left.(\% \mathrm{bl} \mathrm{d})^{-1}\right)\end{array}$ & $\begin{array}{c}\text { migration rate } \\
\left(\mathrm{bl} \mathrm{s}^{-1}\right)\end{array}$ & $\begin{array}{l}\text { FE date } \\
\text { (day } \\
\text { of year) }\end{array}$ & $\begin{array}{l}F E-T_{P} \\
\text { (d) }\end{array}$ & $\begin{array}{l}\mathrm{FE}-\mathrm{T}_{\mathrm{B}} \\
\text { (d) }\end{array}$ & $\begin{array}{l}\text { Adult } \\
\text { returns }\end{array}$ & $\mathrm{n}$ \\
\hline 1999 & $140 \pm 3$ & $167 \pm 2$ & $37 \pm 3$ & $0.80 \pm 0.10$ & $0.59 \pm 0.09$ & $131 \pm 3$ & $40 \pm 3$ & $-3 \pm 3$ & 51133 & $26-30$ (140) \\
\hline 2000 & $141 \pm 4$ & $165 \pm 3$ & $23 \pm 2$ & $0.90 \pm 0.11$ & $0.37 \pm 0.02$ & $121 \pm 2$ & $49 \pm 2$ & $24 \pm 2$ & 34066 & $22-25(62)$ \\
\hline 2002 & $156 \pm 5$ & $160 \pm 4$ & $21 \pm 3$ & $0.45 \pm 0.10$ & $0.40 \pm 0.14$ & $122 \pm 3$ & $42 \pm 3$ & $14 \pm 3$ & 13521 & $16-21(41)$ \\
\hline 2003 & $126 \pm 4$ & $155 \pm 2$ & $31 \pm 3$ & $0.87 \pm 0.16$ & $0.71 \pm 0.09$ & $146 \pm 3$ & $34 \pm 3$ & $-10 \pm 3$ & 14148 & $24-25(72)$ \\
\hline 2004 & $142 \pm 4$ & $147 \pm 3$ & $16 \pm 4$ & $0.38 \pm 0.10$ & $0.28 \pm 0.05$ & $134 \pm 4$ & $24 \pm 4$ & $-12 \pm 4$ & 8535 & 9-24 (38) \\
\hline 2006 & $135 \pm 5$ & $152 \pm 2$ & $26 \pm 2$ & $0.73 \pm 0.08$ & $0.64 \pm 0.08$ & $130 \pm 3$ & $18 \pm 3$ & $-50 \pm 3$ & 12178 & $24-29$ (111) \\
\hline 2007 & $143 \pm 4$ & $158 \pm 3$ & $25 \pm 3$ & $0.67 \pm 0.10$ & $0.50 \pm 0.06$ & $122 \pm 2$ & $48 \pm 2$ & $41 \pm 2$ & 13469 & $26-31$ (85) \\
\hline 2008 & $145 \pm 4$ & $169 \pm 2$ & $26 \pm 3$ & $0.71 \pm 0.12$ & $0.39 \pm 0.10$ & $120 \pm 3$ & $31 \pm 3$ & $56 \pm 3$ & 30539 & $26-30(207)$ \\
\hline
\end{tabular}



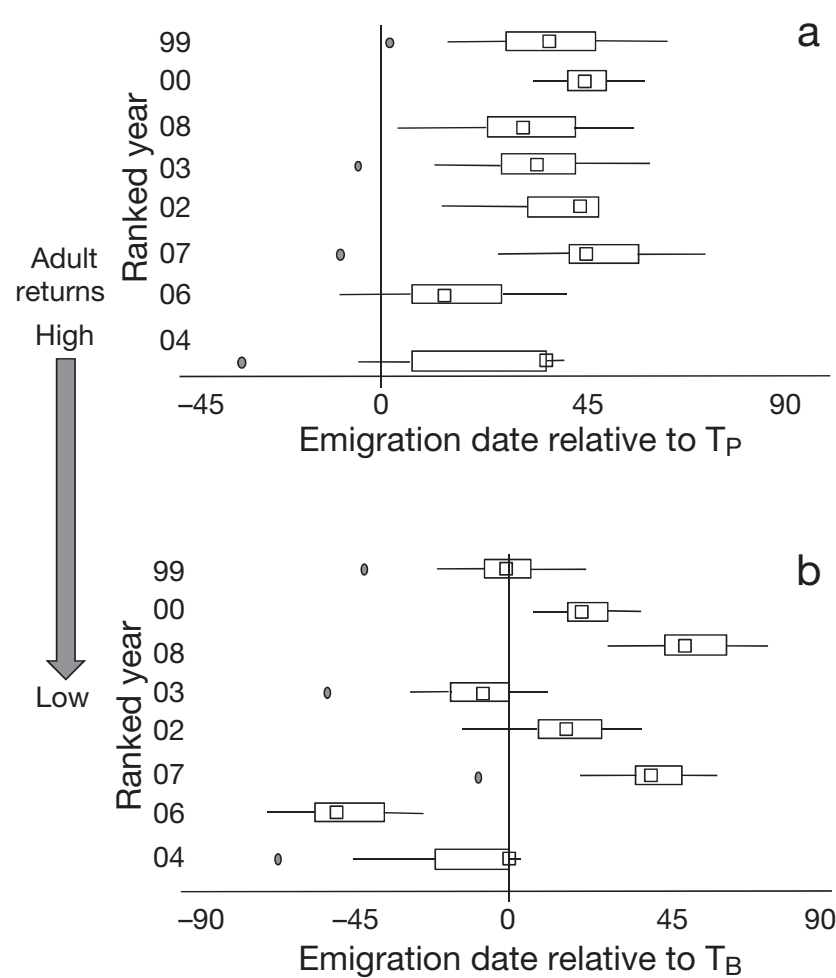

Fig. 3. Oncorhynchus tshawytscha. Dates of freshwater emigration (FE) relative to (a) physical $\left(\mathrm{T}_{\mathrm{P}}\right)$ and (b) biological $\left(\mathrm{T}_{\mathrm{B}}\right)$ spring transitions. Years ranked from highest to lowest adult returns and labeled by juvenile emigration year. Boxes $=$ middle $50 \%$, internal squares = median, whiskers $=$ smallest and largest values within $1.5 \times$ the interquartile range of rectangle edge, ellipses $=$ outliers

(ANOVA: $F_{7,>166}>2.2, \mathrm{p}<0.01$ ). Marine growth rate also varied among years $\left(F_{7,165}=1.8, \mathrm{p}=0.09\right)$. Size $($ mean $\pm \mathrm{SE})$ ranged from $126 \pm 4$ to $156 \pm 5 \mathrm{~mm}$ at freshwater emigration and from $147 \pm 3$ to $168 \pm$ $2 \mathrm{~mm}$ at capture (Table 1). Marine growth rate ranged from $0.38 \pm 0.10$ to $0.90 \pm 0.11 \%$ bl d $\mathrm{d}^{-1}$ (Table 1). Overall, the mean date of emigration ranged from 29 April to 26 May and occurred after the physical spring transition in every year (Fig. 3a) and after the biological spring transition in 4 of the 8 yr (Fig. 3b). Marine migration rate ranged from 0.28 \pm 0.05 to $0.71 \pm 0.09 \mathrm{bl} \mathrm{s}^{-1}$ (Table 1 ), which is equivalent to $3.7 \pm 0.6$ to $7.3 \pm 0.9 \mathrm{~km} \mathrm{~d}^{-1}$.

\section{Back-calculation of size and growth}

The 8 juveniles had been PIT-tagged 20 to $124 \mathrm{~d}$ prior to capture and were released 19 to $104 \mathrm{~d}$ before capture. For these fish, direct and proportional estimates of fish size at tagging were positively correla-
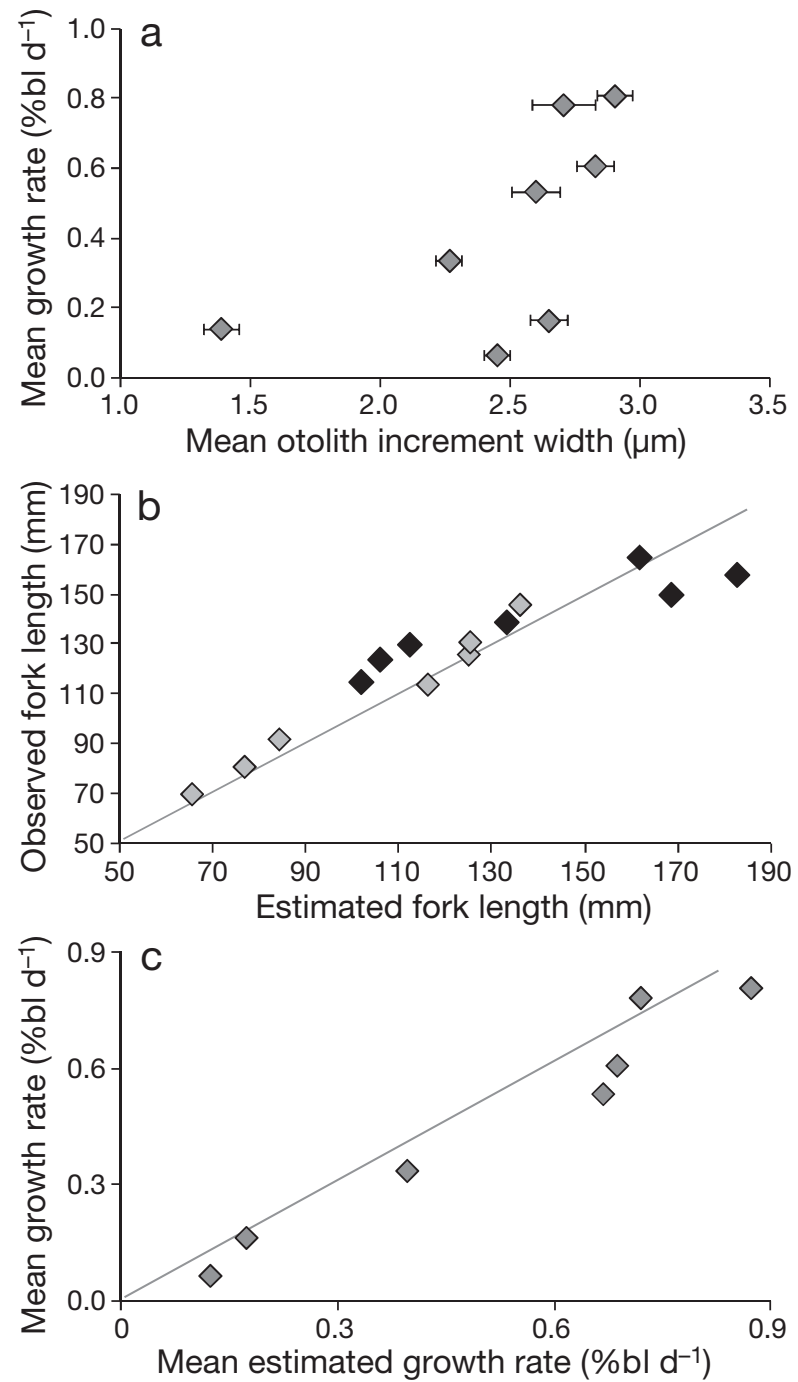

Fig. 4. Oncorhynchus tshawytscha. Relationships between fish and otolith size for interior Columbia River Chinook salmon juveniles with known tagging, size and migration history. (a) Mean somatic growth rate (\%body length [bl] $\mathrm{d}^{-1}$ ) vs. mean \pm SE increment width. (b) Observed vs. estimated fork length at tagging (grey; $\left.\mathrm{r}^{2}=0.98, \mathrm{p}<0.001\right)$ and capture (black; $\mathrm{r}^{2}=0.86, \mathrm{p}=0.002$ ). (c) Observed vs. estimated mean growth rate $(\mathrm{r}=0.97, \mathrm{p}<0.001)$. Estimated growth rate was calculated as: (estimated size at tagging size at capture) $\div$ days since tagging

ted with observed size at tagging $(\mathrm{r}=0.99, \mathrm{p}<0.001$ and $r=0.90, p=0.006$, respectively). However, the accuracy was slightly better and the variation was smaller for direct back-calculation. Therefore, we estimated size at freshwater emigration for the remaining individuals using direct back-calculation (Eq. 1). All estimated lengths at PIT-tagging were within $7 \%$ of observed lengths. For the fish that was most recently tagged, i.e. 20 d prior to capture, tagging size was overestimated by $5 \%$, which made the 
estimated tagging size larger than the actual size at capture. This 'shrinking' fish was excluded from the analysis. For the juveniles collected in the ocean, $7 \%$ ( $n=16)$ were estimated to be 'shrinking' and were excluded from analyses of emigration size and marine growth but included in determination of date of freshwater emigration. Of those fish, 10 had been in marine waters $<20 \mathrm{~d}$.

We found evidence of uncoupling between fish and otolith growth for the 7 PIT-tagged fish included in the growth analyses: mean increment width since tagging was not significantly correlated with somatic growth rate (Fig. $4 \mathrm{a} ; \mathrm{r}=0.40, \mathrm{p}=0.38$ ). Additionally, the relationship between otolith and fish size was stronger at tagging $\left(\mathrm{r}^{2}=0.98, \mathrm{p}<0.001\right)$ than at capture $\left(r^{2}=0.87, p=0.002\right)$. It appears that the uncoupling may have begun shortly prior to capture because back-calculated size at tagging was highly correlated with observed size at tagging (Fig. $4 b_{;} \mathrm{r}^{2}=$ $0.98, \mathrm{p}<0.001)$. We determined that growth estimates generated by subtracting the back-calculated size at tagging from size at capture divided by the days between tagging and capture generated more accurate estimates of growth. Using this approach, estimated growth rate was significantly, positively correlated with observed growth rate (Fig. $4 \mathrm{c} ; \mathrm{r}=$ $0.97, \mathrm{p}<0.001)$. Therefore, we calculated marine growth rate based on size at capture, estimates of size at freshwater emigration, and duration of marine residence.

\section{Growth-mortality hypothesis}

Adult abundance at Priest Rapids Dam was not related to mean size at freshwater emigration (Fig. 5a). However, adult returns were positively related to mean size at capture (Fig. 5b) and marine growth rate (Fig. $5 \mathrm{c}$ ). In fact, interannual variability in adult returns was best described by marine growth rate and an interaction between size at capture and marine growth rate (Table 2; $\mathrm{r}^{2}=0.93, \mathrm{p}=0.001$ ) Year classes with larger mean size at capture and faster early marine growth rate had higher adult returns. Additionally, the interaction term demonstrates that the effect of capture size was not consistent across growth rates. This non-linear effect was mostly driven by 2002, which had large mean size at freshwater emigration and capture but very low growth rate.

Table 2. Oncorhynchus tshawytscha. Model selection criteria for hindcasting interannual variation in adult returns based on juvenile size at capture and marine growth rate. k: number of parameters in model; AICc: Akaike Information Criterion adjusted for small sample size

\begin{tabular}{|c|c|c|c|c|c|}
\hline Model & $\mathrm{k}$ & $\mathrm{n}$ & $\mathrm{AICC}$ & $r^{2}$ & $\mathrm{p}$ \\
\hline Marine growth rate + Size at capture $\times$ Marine growth rate & 3 & 8 & -1.88 & 0.93 & 0.001 \\
\hline Size at capture & 2 & 8 & 1.34 & 0.80 & 0.003 \\
\hline Size at capture + Size at capture $\times$ Marine growth rate & 3 & 8 & 3.99 & 0.86 & 0.007 \\
\hline Size at capture + Marine growth rate & 3 & 8 & 4.38 & 0.86 & 0.008 \\
\hline Size at capture + Marine growth rate + Size at capture $\times$ Marine growth rate & 4 & 8 & 6.45 & 0.94 & 0.006 \\
\hline Size at capture $\times$ Marine growth rate & 2 & 8 & 8.45 & 0.52 & 0.04 \\
\hline Marine growth rate & 2 & 8 & 10.42 & 0.39 & 0.10 \\
\hline
\end{tabular}

Table 3. Oncorhynchus tshawytscha. Correlations between abundance of adults at Priest Rapids Dam and each biological metric, and correlations between biological metrics. Bold is significant: ${ }^{*} p=0.10,{ }^{* *} p<0.10,{ }^{* * *} p<0.05$. FL: fork length; bl: body length; FE: freshwater emigration; physical $\left(\mathrm{T}_{\mathrm{p}}\right)$ and biological $\left(\mathrm{T}_{\mathrm{B}}\right)$ spring transition; Adult returns: abundance of adults returning to Priest Rapids Dam

\begin{tabular}{|c|c|c|c|c|c|c|c|}
\hline & $\begin{array}{c}\text { Size } \\
\text { at FE } \\
(\mathrm{FL}, \mathrm{mm})\end{array}$ & $\begin{array}{c}\text { Marine } \\
\text { growth rate } \\
\left(\% \mathrm{bl} \mathrm{d}^{-1}\right)\end{array}$ & $\begin{array}{l}\text { FE date } \\
\text { (day } \\
\text { of year) }\end{array}$ & $\begin{array}{c}\text { Marine } \\
\text { migration rate } \\
\left(\mathrm{bl} \mathrm{s}^{-1}\right)\end{array}$ & $\begin{array}{l}\mathrm{FE}-\mathrm{T}_{\mathrm{P}} \\
\text { (d) }\end{array}$ & $\begin{array}{l}\mathrm{FE}-\mathrm{T}_{\mathrm{B}} \\
\text { (d) }\end{array}$ & $\begin{array}{l}\text { Adult } \\
\text { returns }\end{array}$ \\
\hline Size at capture (FL, mm) & 0.33 & 0.47 & -0.54 & -0.05 & 0.59 & $0.64^{* *}$ & $0.90^{* * *}$ \\
\hline Size at FE (FL, mm) & & -0.62 & $-0.78^{* * *}$ & $-0.70^{* *}$ & 0.33 & 0.48 & 0.04 \\
\hline Marine growth rate $\left(\% \mathrm{bl} \mathrm{d}{ }^{-1}\right)$ & & & 0.15 & 0.59 & 0.28 & 0.04 & $0.62^{*}$ \\
\hline FE date (day of year) & & & & 0.58 & -0.42 & $-0.63^{* *}$ & -0.30 \\
\hline Marine migration rate $\left(\mathrm{bl} \mathrm{s}{ }^{-1}\right)$ & & & & & -0.15 & -0.47 & 0.07 \\
\hline$F E-T_{P}(d)$ & & & & & & $0.64^{* *}$ & 0.44 \\
\hline$F E-T_{B}(d)$ & & & & & & & 0.38 \\
\hline
\end{tabular}




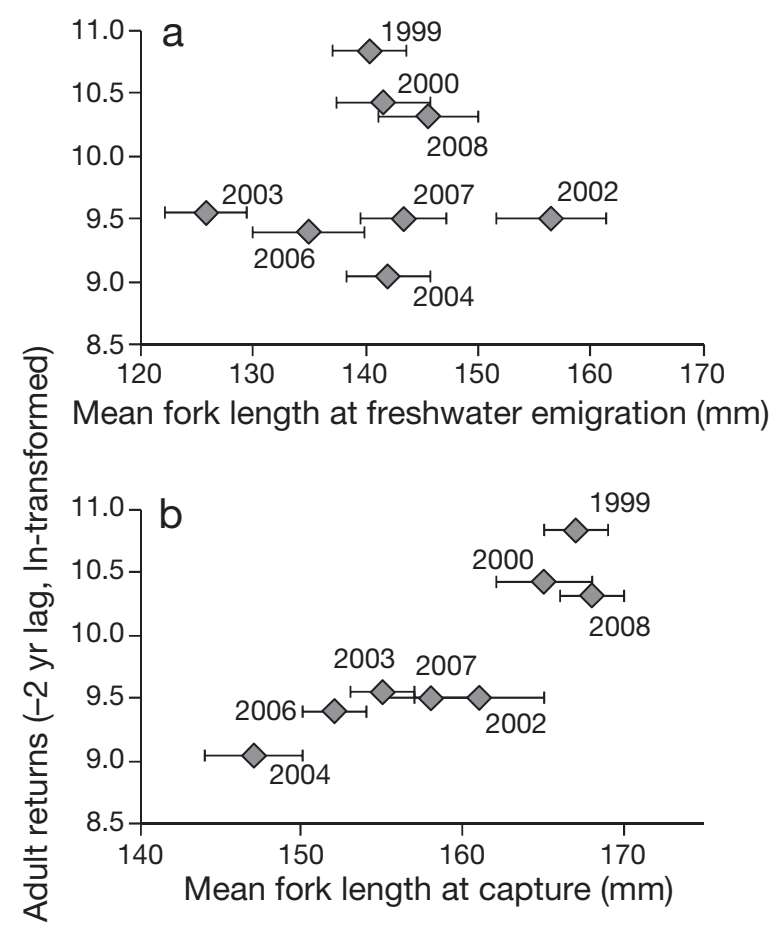

\section{Match-mismatch hypothesis}

Contrary to our predictions, marine growth rate was not significantly correlated with copepod biomass anomalies $(\mathrm{r}=-0.24, \mathrm{p}=0.56)$, the CCI $(\mathrm{r}=-0.15, \mathrm{p}=0.72), \mathrm{FE}-\mathrm{T}_{\mathrm{P}}$ or $\mathrm{FE}-\mathrm{T}_{\mathrm{B}}($ Table 3$)$, although the trends for these pairwise comparisons were in the expected direction. However, size at capture was greater in years with negative values of the $\mathrm{CCI}$, which is indicative of the lipid-rich copepod community (Fig. 6a; r = -0.90, p = 0.002) and earlier biological transitions, i.e. a greater FE- $\mathrm{T}_{\mathrm{B}}$ (Fig. $6 \mathrm{~b}_{\mathrm{r}} \mathrm{r}=$ $0.64, p=0.09$ ). Size at capture was not related to the copepod biomass anomaly $(\mathrm{r}=0.49, \mathrm{p}=0.22)$ or FE$\mathrm{T}_{\mathrm{P}}$ (Table 3).

We observed that juveniles migrated more slowly during periods when the copepod biomass was relatively high (Fig. 7a; $r=-0.68, p=0.06$ ). Migration rate was not significantly correlated with $\mathrm{FE}_{\mathrm{P}} \mathrm{T}_{\mathrm{P}}$ or FE- $_{\text {B }}$ (Table 3$)$, or CCI $(\mathrm{r}=0.38, \mathrm{p}=0.36)$, although the trends for all 3 variables were in the expected direction if spatiotemporal overlap with highly productive conditions influenced the time spent in coastal waters. Additionally, we observed that marine migration rate was positively related to the date of freshwater emigration for individual fish collected in both May $(\mathrm{r}=0.59, \mathrm{p}<0.0001)$ and June $(\mathrm{r}=0.67$, $\mathrm{p}<0.0001$ ) (Fig. 7b). Fish emigrating from the Columbia River later in the year tended to move northward more quickly than those emigrating earlier in the year.

\section{DISCUSSION}

5. Oncorhynchus tshawytscha. Adult returns to Priest Rapids Dam ( -2 yr lag) vs. juvenile fork length (mean $\pm \mathrm{SE}$ ) at (a) freshwater emigration $\left(\mathrm{r}^{2}=0.001, \mathrm{df}=6, \mathrm{p}=0.93\right)$ and (b) capture $\left(\mathrm{r}^{2}=0.80, \mathrm{df}=6, \mathrm{p}=0.003\right)$, and (c) marine growth rate (mean $\left.\pm \mathrm{SE}_{i} \mathrm{r}^{2}=0.39, \mathrm{df}=6, \mathrm{p}=0.10\right)$. $\mathrm{bl}=$ body length; labels = juvenile emigration year
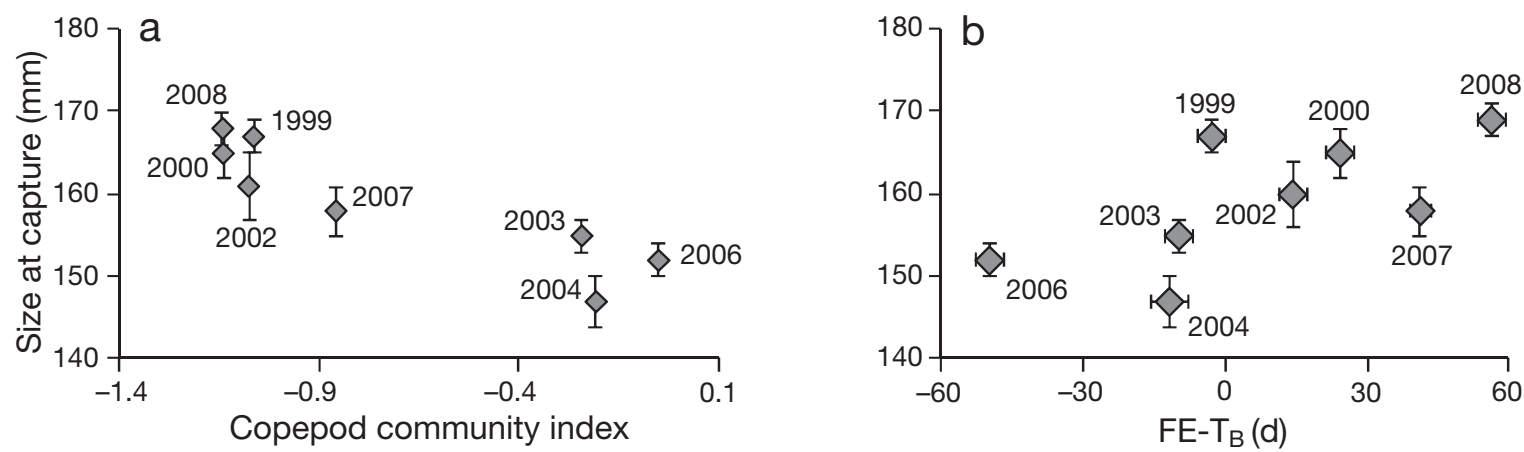

Fig. 6. Oncorhynchus tshawytscha. Relationships between juvenile size at capture and indices of ocean productivity. Fork length at capture (mean $\pm \mathrm{SE}$ ) vs. (a) copepod community index $\left(\mathrm{CCI}_{;} \mathrm{r}=-0.90, \mathrm{p}=0.002\right)$ and (b) time between freshwater emigration and the biological spring transition $\left(F E-T_{B}, d_{i} r=0.64, p=0.09\right)$. Labels $=$ juvenile emigration year 

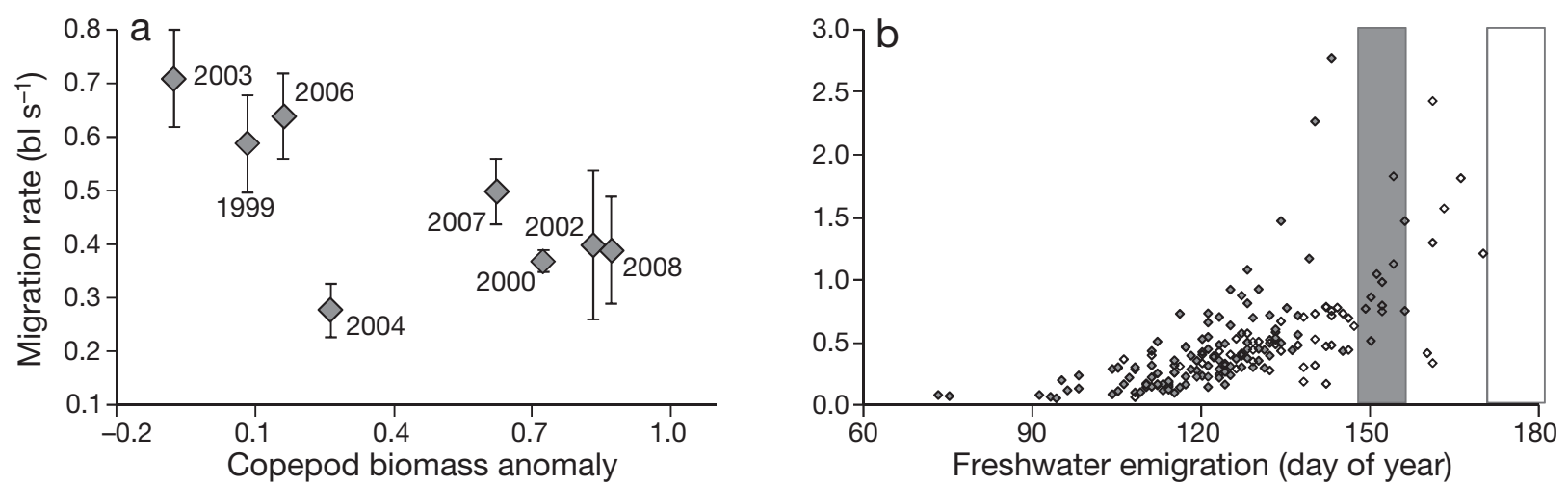

Fig. 7. Oncorhynchus tshawytscha. (a) Migration rate (mean \pm SE) vs. copepod biomass anomaly $(r=-0.68, p=0.06)$. Labels $=$ juvenile emigration year. (b) Marine migration rate (mean $\pm \mathrm{SE}$ ) vs. date of freshwater emigration for fish collected in May $(\diamond: \mathrm{r}=0.59, \mathrm{df}=126, \mathrm{p}<0.001)$ and June $(\diamond: \mathrm{r}=0.67, \mathrm{df}=67, \mathrm{p}<0.001) . \mathrm{bl}=$ body length. Boxes = May (grey) and June (open) collection dates

integrated approach allowed us to evaluate factors that can influence survival during early ocean residence and, therefore, may regulate future adult abundance. We excluded 2 low-catch years, 2001 and 2005, from our analysis; ocean conditions during these years were also poor. The physical spring transition was late in both years and in 2005 cumulative upwelling was anomalously low and sea surface temperature was anomalously high (Pierce et al. 2006). Our results provide strong support for the cumulative growth (size) and growth rate mechanisms of the growth-mortality hypothesis. Although results for the match-mismatch hypothesis were less clear, there was some evidence that juvenile size is related to interannual variation in the timing and composition of production in lower trophic levels. Furthermore, we observed seasonal and interannual variation in migratory behavior that may be related, in part, to foraging conditions.

Body size has previously been demonstrated to be important for survival of juvenile salmonids (Bilton et al. 1982, Henderson \& Cass 1991) and many other fishes (for reviews, see Anderson 1988, Sogard 1997). For Chinook salmon, the relative importance of size at freshwater emigration compared with other periods in the life history has been difficult to evaluate. Studies often compare size at release from hatcheries, which is biased and does not provide information on the specific size at marine entry. Our results provide no evidence that interannual variation in size at freshwater emigration, based on our $\mathrm{Sr}: \mathrm{Ca}$ ratio work, was related to future adult abundance. Variation in size at capture may be caused by growth ratedependent or size-dependent mortality or a combination of these factors. Similar to Duffy \& Beauchamp (2011), we observed that size shortly after marine residence was positively related to adult returns (or survival). Given that we also observed positive (although weaker) relationships between marine growth rate and future adult returns, it is plausible that a combination of interannual variation in marine growth rate and size-selective survival influenced body size by May and June. If there was strong sizeselective mortality when juveniles initially entered the marine environment, we may not be able to detect it because we only sampled individuals that survived 1 to $75 \mathrm{~d}$ of marine residence. However, for the $8 \mathrm{yr}$ examined in this study, size at marine entry did not account for any of the subsequent variation in adult returns whereas size after an average of $30 \mathrm{~d}$ of marine residence accounted for $\sim 80 \%$ of that variation. This observation indicates that processes shortly after initial marine entry play a larger role in determination of cohort strength than those occurring at the time of marine entry.

Early marine growth was not related to the timing of the physical and biological transition in relation to marine entry. The consistent observation that juveniles emigrated after the spring transition suggests that the emigration timing of mid-upper Columbia River spring Chinook salmon may be an adaptation to the long-term pattern of seasonal upwelling (Taylor 1990, Via et al. 1995). Additionally, the similarity in emigration timing across years may also be influenced by the similar timing of hatchery release across years ( 3.5 wk) (Regional Mark Information System, www.rmpc.org). Previous studies found that, for hatchery Chinook salmon, subyearling juveniles that emigrated earlier in the year had higher survival (Duffy \& Beauchamp 2011) and individual survival probability was highest for yearling fish migrating during the first half of May (Scheuerell et al. 2009). 
These 2 previous studies examined intra-annual variation in migration timing while we focused on interannual variability. While relative interannual stability in emigration timing may be adaptive for the population as a whole, intra-annual variation in migration timing may result in differential survival within a year-class, i.e. an early migrating contingent of the stock may experience relatively higher survival (Kraus \& Secor 2004b).

We did find evidence that juvenile size at capture was related to ocean conditions during early marine residence. Juvenile size at capture was related to the community structure of copepods in coastal shelf waters. Body size was greater when the CCI indicated that cold-water copepods were dominant. Juvenile Chinook salmon do not eat copepods (Peterson et al. 1982, Schabetsberger et al. 2003, Daly et al. 2009, Miller et al. 2010b), so this obviously does not demonstrate a direct link to prey. However, it does suggest that foraging conditions are related to the structure of the zooplankton community. One potential mechanism for the link between juvenile size and the $\mathrm{CCI}$ is that variation in the nutritional quality of secondary producers influences yearling Chinook salmon prey, which is usually dominated by larval fishes and decapods (Daly et al. 2009, 2011). There is some evidence that the lipid composition of potential prey varies with ocean conditions (Litzow et al. 2006, Litz et al. 2010). Alternatively, the CCI may provide a relative indicator of larger-scale ocean conditions that are beneficial to juvenile salmon survival rather than indicate a direct trophic linkage.

Interannual variation in growth rate was not related to the copepod community structure. If size was related to the copepod community via trophic linkages then one might expect growth rate to also be higher when the CCI indicates that lipid-rich copepods are present. The relationship between growth rate and the $\mathrm{CCI}$ trended the same direction as the relationship between capture size and the CCI, but was not significant. Potential explanations for this unexpected finding deserve some exploration. Size at capture was based on all fish caught in each year while growth rate was based on a subsample for which otoliths were available. It is possible that a derived metric of growth rate based on a smaller sample may not represent interannual variation as well as body size at capture. Additionally, there is some indication that the juveniles from the midupper Columbia River stock group included in this study may represent a subset of slower migrating individuals. For example, the mean migration rates observed in this study ( 3.7 to $7.3 \mathrm{~km} \mathrm{~d}^{-1}$ ) were slower than some previous estimates based on fish with CWTs (9.7 to 10.4 and 10 to $20 \mathrm{~km} \mathrm{~d}^{-1}$ ) (Trudel et al. 2009, J. P. Fisher, Oregon State University, Newport, OR, unpubl. data). The mean date of marine entry observed in this study was prior to May 13th in all but one year. Therefore, it is likely that faster migrants were northward of our sampling grid before the cruise at the end of May. The fish that were collected during the late May and June collections may represent slower migrating individuals with somewhat different growth characteristics than the overall population. Growth can be related to temperature and one might expect ocean temperature to influence the marine growth rate; however, we found no evidence that growth rate was related to sea surface temperature in the study region (data not shown).

The observation that the mean migration rate was slower when copepod biomass anomalies were higher demonstrates interannual variability in migratory behavior. Migration rate may be a response to foraging conditions. Fish may migrate more slowly when foraging conditions are good. Alternatively, high biomass anomalies correspond to periods of upwelling (Hooff \& Peterson 2006), which usually correspond to enhanced southward, alongshore transport (Strub et al. 1987). Therefore, the net migration rate of juvenile salmon may be slower during periods with high biomass anomalies. Coastal sea level height is related to the intensity of equatorward current and offshore advection (Strub et al. 1987, Checkley \& Barth 2009). However, we found no relationships between migration rate and interannual variation in sea level height or alongshore transport during spring and early summer (data not shown). Nevertheless, regardless of the underlying mechanism, it appears that at least some juveniles migrate northward more slowly and, thus, spend more time in the local coastal waters during periods of greater copepod biomass.

The relationship between migration rate and emigration timing indicates consistent intra-annual patterns in migration rate. Later emigrants migrated faster across all years, which suggests that migratory behavior may be partially a seasonal response. One potential explanation is that individual migration rate may be influenced by some type of circadian rhythm (Gibson et al. 1978, Meseguer et al. 2008, LopezOlmeda \& Sanchez-Vazquez 2009).

We were able to successfully isolate an important period in the life history of spring Chinook salmon-marine entry-to evaluate the relative importance of the size and timing of juvenile Chinook salmon upon marine entry. Across $8 \mathrm{yr}$, we found no 
evidence that the annual variation in mean size at marine entry was related to subsequent abundance. However, size after $\sim 1$ mo of marine residence was highly correlated with adult abundance, which suggests that processes occurring shortly after marine entry may be more important for understanding mechanisms that establish cohort size. Furthermore, we were able to provide data on migratory characteristics at the individual level that highlight interannual and seasonal variation that may be influenced by foraging conditions. Overall, combined approaches that incorporate genetic analyses to estimate stock-of-origin with individual-level otolith analyses hold great promise to provide detailed information at the necessary scales to understand stock-specific adaptation and identify mechanisms regulating interannual variation in population size.

Acknowledgements. A. Paul and J. Unrein assisted with otolith preparation. A. Ungerer assisted with LA-ICPMS. L. Weitkamp provided the PIT-tagged juveniles for the backcalculation techniques comparison and constructive criticisms on an earlier draft of this paper. The Columbia River Inter-Tribal Fish Commission provided the 2010 age-composition of spring-run Chinook salmon at Bonneville Dam. The comments of 4 anonymous reviewers strengthened this paper. Funding was provided by Bonneville Power Administration, NOAA Fisheries, and a Mamie Markham Research Award.

\section{LITERATURE CITED}

Anderson JT (1988) A review of size dependent survival during pre-recruit stages of fishes in relation to recruitment. J Northwest Atl Fish Sci 8:55-66

> Bailey KM, Batty RS (1983) A laboratory study of predation by Aurelia aurita on larval herring (Clupea harengus): experimental observations compared with model predictions. Mar Biol 72:295-301

Beacham TD, Candy JR, Jonsen KL, Supernault J and others (2006) Estimation of stock composition and individual identification of Chinook salmon across the Pacific Rim by use of microsatellite variation. Trans Am Fish Soc 135: 861-888

> Beamish RJ, Mahnken C (2001) A critical size and period hypothesis to explain natural regulation of salmon abundance and the linkage to climate and climate change. Prog Oceanogr 49:423-437

> Beamish RJ, Mahnken C, Neville CM (2004) Evidence that reduced early marine growth is associated with lower marine survival of coho salmon. Trans Am Fish Soc 133: 26-33

Beckman BR, Dickhoff WW, Zaugg WS, Sharpe C and others (1999) Growth, smoltification, and smolt-to-adult return of spring Chinook salmon from hatcheries on the Deschutes River, Oregon. Trans Am Fish Soc 128:1125-1150

Bilton HT, Alderdice DF, Schnute JT (1982) Influence of time and size at release of juvenile coho salmon (Oncorhynchus kisutch) on returns at maturity. Can J Fish Aquat Sci 39:426-447
Blaxter JHS (1986) Development of sense organs and behaviour of teleost larvae with special reference to feeding and predator avoidance. Trans Am Fish Soc 115:98-114

Brodeur RD, Pearcy WG (1990) Trophic relations of juvenile Pacific Salmon off the Oregon and Washington coast. Fish Bull 88:617-636

Butler JL, Pickett D (1988) Age-specific vulnerability of Pacific sardine, Sardinops sagax, larvae to predation by northern anchovy, Engraulis mordax. Fish Bull 86: 163-167

Campana SE, Jones CM (1992) Analysis of otolith microstructure data. In: Stevenson DK, Campana SE (eds) Otolith microstructure examination and analysis. Can Spec Publ Fish Aquat Sci 117:73-100

> Chambers RC, Leggett WC (1987) Size and age at metamorphosis in marine fishes: an analysis of laboratory-reared winter flounder (Pseudopleuronectes americanus) with a review of variation in other species. Can J Fish Aquat Sci 44:1936-1947

> Chawla A, Jay DA, Baptista AM, Wilkin M, Seaton C (2008) Seasonal variability and estuary-shelf interactions in circulation dynamics of a river-dominated estuary. Estuaries Coasts 31:269-288

Checkley DM Jr, Barth JA (2009) Patterns and processes in the California Current System. Prog Oceanogr 83:49-64

Cross AD, Beauchamp DA, Myers KW, Moss JH (2008) Early marine growth of pink salmon in Prince William Sound and the coastal Gulf of Alaska during years of low and high survival. Trans Am Fish Soc 137:927-939

Cross AD, Beauchamp DA, Moss JH, Myers KW (2009) Interannual variability in early marine growth, sizeselective mortality, and marine survival for Prince William Sound pink salmon. Mar Coast Fish Dyn Manage Ecosyst Sci 1:57-70

Cushing DH (1974) The natural regulation of fish populations. In: Harden Jones FR (ed) Sea fisheries research. Wiley, London, p 399-412

Cushing DH (1990) Plankton production and year-class strength in fish populations: an update of the match/mismatch hypothesis. Adv Mar Biol 26:249-293

Daly EA, Brodeur RD, Weitkamp LA (2009) Ontogenetic shifts in diets of juvenile and subadult coho and Chinook salmon in coastal marine waters: important for marine survival? Trans Am Fish Soc 138:1420-1438

Daly EA, Brodeur RD, Fisher JP, Weitkamp LA, Teel DJ, Beckman BR (2011) Spatial and trophic overlap of marked and unmarked Columbia River Basin spring Chinook salmon during marine residence with implications for competition between hatchery and naturally produced fish. Environ Biol Fish 94:117-134

> Duffy EJ, Beauchamp DA (2011) Rapid growth in the early marine period improves the marine survival of Chinook salmon (Oncorhynchus tshawytscha) in Puget Sound, Washington. Can J Fish Aquat Sci 68:232-240

> Emmett RL, Krutzikowsky GK (2008) Nocturnal feeding of Pacific hake and jack mackerel off the mouth of the Columbia River, 1998-2004: implications for juvenile salmon predation. Trans Am Fish Soc 137:657-676

Emmett RL, Krutzikowsky GK, Bentley P (2006) Abundance and distribution of pelagic piscivorous fishes in the Columbia River plume during spring/early summer 19982003: relationship to oceanographic conditions, forage fishes, and juvenile salmonids. Prog Oceanogr 68:1-26

Francis RICC (1990) Back-calculation of fish length: a critical review. J Fish Biol 36:883-902 
Fryer JK (2009) Estimation of mid-Columbia summer Chinook salmon escapement and age composition using PIT tags in 2008. Tech Rep 09-04, Columbia River InterTribal Fish Commission, Portland, OR

Gibson RN, Blaxter JHS, de Groot SJ (1978) Developmental changes in the activity rhythms of the plaice (Pleuronectes platessa L.). In: Thorpe JE (ed) Rhythmic activity of fishes. Academic Press, New York, NY, p 169-186

Giorgi AE, Miller DR, Sandford BP (1994) Migratory characteristics of juvenile ocean-type Chinook salmon, Oncorhynchus tshawytscha, in John Day Reservoir on the Columbia River. Fish Bull 92:872-879

Good TP, Waples RS, Adams P (eds) (2005) Updated status of federally listed ESUs of West Coast salmon and steelhead. NOAA Tech Memo NMFS-NWFSC-66

Hare SR, Mantua NJ, Francis RC (1999) Inverse production regimes: Alaska and West Coast Pacific salmon. Fisheries (Bethesda, Md) 24:6-14

Henderson MA, Cass AJ (1991) Effect of smolt size on smoltto-adult survival for Chilko Lake sockeye salmon (Oncorhynchus nerka). Can J Fish Aquat Sci 48:988-994

Henson SA, Thomas AC (2007) Interannual variability in timing of bloom initiation in the California Current System. J Geophys Res 112:C08007. doi:10.1029/2006JC003960

Hooff RC, Peterson WT (2006) Copepod biodiversity as an indicator of changes in ocean and climate conditions of the northern California Current ecosystem. Limnol Oceanogr 51:2607-2620

Houde ED (1987) Fish early life dynamics and recruitment variability. Am Fish Soc Symp 2:17-29

Houde ED (2008) Emerging from Hjort's shadow. J Northwest Atl Fish Sci 41:53-70

Kalinowski ST, Manlove KR, Taper ML (2007) ONCOR: a computer program for genetic stock identification. Department of Ecology, Montana State University, Bozeman, MT, available online at: www.montana.edu/kalinowski/Software/ONCOR.htm

Keister JE, Peterson WT, Pierce SD (2009) Zooplankton distribution and cross-shelf transfer of carbon in an area of complex mesoscale circulation in the northern California Current. Deep-Sea Res I 56:212-231

Keister JE, Di Lorenzo E, Morgan CA, Combes V, Peterson WT (2011) Zooplankton species composition is linked to ocean transport in the northern California Current. Glob Change Biol 17:2498-2511

> Kraus RT, Secor DH (2004a) Incorporation of strontium into otoliths of an estuarine fish. J Exp Mar Biol Ecol 302: 85-106

Kraus RT, Secor DH (2004b) Dynamics of white perch Morone americana population contingents in the Patuxent River estuary, Maryland, USA. Mar Ecol Prog Ser 279:247-259

> Litz MNC, Brodeur RD, Emmett RL, Heppell SS, Rasmussen RS, O'Higgins L, Morris MS (2010) Effects of variable oceanographic conditions on forage fish lipid content and fatty acid composition in the northern California Current. Mar Ecol Prog Ser 405:71-85

> Litzow MA, Bailey KM, Prahl FG, Heintz R (2006) Climate regime shifts and reorganization of fish communities: the essential fatty acid limitation hypothesis. Mar Ecol Prog Ser 315:1-11

Logerwell EA, Mantua N, Lawson PW, Francis RC, Agostini VN (2003) Tracking environmental processes in the coastal zone for understanding and predicting Oregon coho (Oncorhynchus kisutch) marine survival. Fish
Oceanogr 12:554-568

Lopez-Olmeda JF, Sanchez-Vazquez FJ (2009) Zebrafish temperature selection and synchronization of locomotor activity circadian rhythm to ahemeral cycles of light and temperature. Chronobiol Int 26:200-218

Meseguer C, Ramos J, Bayarri MJ, Oliveira C, SanchezVazquez FJ (2008) Light synchronization of the daily spawning rhythms of gilthead sea bream (Sparus aurata L) kept under different photoperiod and after shifting the LD cycle. Chronobiol Int 25:666-679

Miller JA (2007) Scales of variation in otolith elemental chemistry of juvenile staghorn sculpin (Leptocottus armatus) in three Pacific Northwest estuaries. Mar Biol 151:483-494

> Miller JA (2009) The effects of temperature and water concentration on the otolith incorporation of barium and manganese in black rockfish Sebastes melanops. J Fish Biol 75:39-60

Miller JA (2011) Effects of water temperature and barium concentration on otolith composition along a salinity gradient: implications for migratory reconstructions. J Exp Mar Biol Ecol 405:42-52

Miller TJ, Crowder LB, Rice JA, Marschall EA (1988) Larval size and recruitment mechanisms in fishes: toward a conceptual framework. Can J Fish Aquat Sci 45:1657-1670

Miller JA, Gray A, Merz J (2010a) Quantifying the contribution of juvenile migratory phenotypes in a population of Chinook salmon Oncorhynchus tshawytscha. Mar Ecol Prog Ser 408:227-240

> Miller TW, Brodeur RD, Rau G, Omori K (2010b) Prey dominance shapes trophic structure of the northern California Current pelagic food web: evidence from stable isotopes and diet analysis. Mar Ecol Prog Ser 420:15-26

Miller JA, Butler VL, Simenstad CA, Backus DH, Kent AJR (2011) Life history variation in upper Columbia River Chinook salmon (Oncorhynchus tshawytscha): a comparison using modern and $~ 500$-year-old archaeological otoliths. Can J Fish Aquat Sci 68:603-617

Moss JH, Beauchamp DA, Cross AD, Myers KW, Farley EV Jr, Murphy JM, Helle JH (2005) Evidence for size-selective mortality after the first summer of ocean growth by pink salmon. Trans Am Fish Soc 134:1313-1322

Myers JM, Kope RG, Bryant GJ, Teel D and others (1998) Status review of Chinook salmon from Washington, Idaho, Oregon, and California. NOAA Tech Memo NMFS-NWFSC-35

Neilson JD, Geen GH (1982) Otoliths of Chinook salmon (Oncorhynchus tshawytscha): daily growth increments and factors influencing their production. Can J Fish Aquat Sci 39:1340-1347

Neilson JD, Geen GH (1985) Effects of feeding regimes and diel temperature cycles on otolith increment formation in juvenile Chinook salmon, Oncorhynchus tshawytscha. Fish Bull 83:91-101

Pearcy WG (1992) Ocean ecology of North Pacific salmonids. In: Johnson A (ed) Books in recruitment fishery oceanography. University of Washington Press, Seattle, WA

Pearcy WG, McKinnell SM (2007) The ocean ecology of salmon in the northeast Pacific Ocean: an abridged history. Am Fish Soc Symp 57:7-30

> Peterman RM, Pyper BJ, Lapointe MF, Adkison MD, Walters CJ (1998) Patterns of covariation in survival rates of British Columbian and Alaskan sockeye salmon (Oncorhynchus nerka) stocks. Can J Fish Aquat Sci 55: 2503-2517 
Peterson WT (2009) Copepod species richness as an indicator of long-term changes in the coastal ecosystem of the northern California Current. Calif Coop Ocean Fish Invest Rep 50:73-81

> Peterson WT, Schwing FB (2003) A new climate regime in northeast Pacific ecosystems. Geophys Res Lett 30: 1896-1899

Peterson WT, Brodeur RD, Pearcy WG (1982) Food habits of juvenile salmon in the Oregon coastal zone, June 1979. Fish Bull 80:841-851

Petrosky CE, Schaller HA (2010) Influence of river conditions during seaward migration and ocean conditions on survival rates of Snake River Chinook salmon and steelhead. Ecol Freshwat Fish 19:520-536

Pierce SD, Barth JA, Thomas RE, Fleischer GW (2006) Anomalously warm July 2005 in the northern California Current: historical context and the significance of cumulative wind stress. Geophys Res Lett 33:L22S04. doi: 10.1029/2006GL027149

> Pyper BJ, Mueter FJ, Peterman RM (2005) Across-species comparisons of spatial scales of environmental effects on survival rates of northeast Pacific salmon. Trans Am Fish Soc 134:86-104

Quinn TP, Myers KW (2004) Anadromy and the marine migrations of Pacific salmon and trout: Rounsefell revisited. Rev Fish Biol Fish 14:421-442

Rannala B, Mountain JL (1997) Detecting immigration by using multilocus genotypes. Proc Natl Acad Sci USA 94: 9197-9201

Rich WH (1920) Early history and seaward migration of Chinook salmon in the Columbia and Sacramento rivers. Fish Bull 37:1-73

Schabetsberger R, Morgan CA, Brodeur RD, Potts CL, Peterson WT, Emmett RL (2003) Prey selectivity and diel feeding chronology of juvenile Chinook (Oncorhynchus tshawytscha) and coho (O. kisutch) salmon in the Columbia River plume. Fish Oceanogr 12:523-540

Scheuerell MD, Williams JG (2005) Forecasting climateinduced changes in the survival of Snake River spring/ summer Chinook salmon (Oncorhynchus tshawytscha). Fish Oceanogr 14:448-457

Scheuerell MD, Zabel RW, Sandford BP (2009) Relating juvenile migration timing and survival to adulthood in two species of threatened Pacific salmon (Oncorhynchus spp.). J Appl Ecol 46:983-990

Secor DH (1992) Application of otolith microchemistry analysis to investigate anadromy in Chesapeake Bay striped bass Morone saxatilis. Fish Bull 90:798-806

Seeb LW, Antonovich A, Banks MA, Beacham TD and others (2007) Development of a standardized DNA database for Chinook salmon. Fisheries (Bethesda, Md) 32:540-552

Sogard SM (1997) Size-selective mortality in the juvenile stage of teleost fishes: a review. Bull Mar Sci 60:1129-1157

Strub PT, Allen JS, Huyer A, Smith RL, Beardsley RC (1987) Seasonal cycles of currents, temperatures, winds, and sea level over the northeast Pacific continental shelf: $35^{\circ} \mathrm{N}$ to $48^{\circ} \mathrm{N}$. J Geophys Res 92:1507-1526
Takasuka A, Aoki I, Mitani I (2004) Three synergistic growth-related mechanisms in the short-term survival of larval Japanese anchovy Engraulis japonicus in Sagami Bay. Mar Ecol Prog Ser 270:217-228

Taylor EB (1990) Phenotypic correlates of life-history variation in juvenile Chinook salmon, Oncorhynchus tshawytscha. J Anim Ecol 59:455-468

Teel DJ, Baker C, Kuligowski DR, Friesen TA, Shields B (2009) Genetic stock composition of subyearling Chinook salmon in seasonal floodplain wetlands of the lower Willamette River, Oregon. Trans Am Fish Soc 138: 211-217

> Tiffan KF, Rondorf DW, Wagner PG (2000) Physiological development and migratory behavior of subyearling fall Chinook salmon in the Columbia River. N Am J Fish Manage 20:28-40

- Trudel M, Fisher J, Orsi JA, Morris JFT and others (2009) Distribution and migration of juvenile Chinook salmon derived from coded wire tag recoveries along the continental shelf of western North America. Trans Am Fish Soc 138:1369-1391

Tuomikoski J, McCann J, Berggren T, Schaller H and others (2011) Comparative survival study (CSS) of PIT-tagged spring/summer Chinook and summer steelhead. 2011 annual report. BPA Contract no. 19960200, Comparative Survival Study Oversight Committee and Fish Passage Center, Portland, OR

> Unwin MJ (1997) Fry-to-adult survival of natural and hatchery-produced Chinook salmon (Oncorhynchus tshawytscha) from a common origin. Can J Fish Aquat Sci 54: 1246-1254

> Via S, Gomulkiewicz R, De Jong G, Scheiner SM, Schlichting CD, Van Tienderen PH (1995) Adaptive phenotypic plasticity: consensus and controversy. Trends Ecol Evol 10:212-217

Waples RS, Zabel RW, Scheuerell MD, Sanderson BL (2008) Evolutionary responses by native species to major anthropogenic changes to their ecosystems: Pacific salmon in the Columbia River hydropower system. Mol Ecol 17: $84-96$

- Ward BR, Slaney PA (1988) Life history and smolt-to-adult survival of Keogh River steelhead trout (Salmo gairdneri) and the relationship to smolt size. Can J Fish Aquat Sci 45:1110-1122

> Weitkamp LA (2010) Marine distributions of Chinook salmon from the West Coast of North America determined by coded wire tag recoveries. Trans Am Fish Soc 139:147-170

Zabel RW, Achord S (2004) Relating size of juveniles to survival within and among populations of Chinook salmon. Ecology 85:795-806

Zabel RW, Williams JG (2002) Selective mortality in Chinook salmon: What is the role of human disturbance? Ecol Appl 12:173-183

- Zimmerman CE (2005) Relationship of otolith strontium-tocalcium ratios and salinity: experimental validation for juvenile salmonids. Can J Fish Aquat Sci 62:88-97 


\section{Appendix 1.}

Table A1. Oncorhynchus tshawytscha. Numbers of fish whose otoliths were used in this study by collection transect, month, and year. Otolith samples were selected in proportion to number of fish collected at each transect. See Fig. 1 for transect locations

\begin{tabular}{|c|c|c|c|c|c|c|c|c|c|}
\hline & Year & $\begin{array}{l}\text { May } \\
\text { (n) }\end{array}$ & $\begin{array}{l}\text { June } \\
\text { (n) }\end{array}$ & $\begin{array}{c}\text { Transect } \\
\text { total }\end{array}$ & & Year & $\begin{array}{l}\text { May } \\
\text { (n) }\end{array}$ & $\begin{array}{l}\text { June } \\
\text { (n) }\end{array}$ & $\begin{array}{c}\text { Transect } \\
\text { total }\end{array}$ \\
\hline Tatoosh Island & 2003 & & 1 & 1 & Willapa Bay & 2003 & & 1 & \\
\hline Father and Son & $\begin{array}{l}2006 \\
2007\end{array}$ & 3 & 4 & $\underline{7}$ & & $\begin{array}{l}2006 \\
2007 \\
2008\end{array}$ & $\begin{array}{r}6 \\
14 \\
4\end{array}$ & & 25 \\
\hline La Push & $\begin{array}{l}1999 \\
2003 \\
2006 \\
2007\end{array}$ & 5 & $\begin{array}{r}26 \\
12 \\
5 \\
1\end{array}$ & $\underline{49}$ & Columbia River & $\begin{array}{l}2000 \\
2002 \\
2003 \\
2004\end{array}$ & $\begin{array}{l}12 \\
17 \\
20\end{array}$ & 6 & \\
\hline Queets River & $\begin{array}{l}2003 \\
2004 \\
2006 \\
2007 \\
2008\end{array}$ & $\begin{array}{l}5 \\
6 \\
4\end{array}$ & $\begin{array}{l}9 \\
2 \\
1\end{array}$ & $\underline{27}$ & & $\begin{array}{l}2006 \\
2007 \\
2008\end{array}$ & $\begin{array}{r}3 \\
4 \\
22\end{array}$ & 2 & $\underline{86}$ \\
\hline Grays Harbor & $\begin{array}{l}1999 \\
2000 \\
2002 \\
2004 \\
2006 \\
2007\end{array}$ & $\begin{array}{r}14 \\
5 \\
4 \\
2 \\
4\end{array}$ & 1 & $\underline{36}$ & & & & & \\
\hline
\end{tabular}

Editorial responsibility: Edward Durbin, Narragansett, Rhode Island, USA
Submitted: July 27, 2011; Accepted: January 24, 2012

Proofs received from author(s): April 9, 2012 